\title{
Readiness of Polish Industrial Enterprises for the Industry 4.0 Revolution
}

\author{
Marcin Lis ${ }^{1, *(\mathbb{D}}$, Bartosz Jeżyna ${ }^{1, * \mathbb{D}}$, Ewa Szkudlarek ${ }^{1}$ and Szymon Szumiał ${ }^{2} \mathbb{D}$ \\ 1 Department of Management, Faculty of Applied Sciences, WSB University, 41-300 Dąbrowa Górnicza, Poland; \\ eszkudlarek@wsb.edu.pl \\ 2 Faculty of Management, University of Warsaw, 02-678 Warsaw, Poland; sszumial@wz.uw.edu.pl \\ * Correspondence: mlis@wsb.edu.pl (M.L.); bjezyna@wsb.edu.pl (B.J.)
}

Citation: Lis, Marcin, Bartosz Jeżyna, Ewa Szkudlarek, and Szymon Szumiał. 2021. Readiness of Polish Industrial Enterprises for the Industry 4.0 Revolution. Social Sciences 10: 214. https://doi.org/10.3390/ socsci10060214

Academic Editors: Hana Štverková, Beata Slusarczyk and Aneta Pachura

Received: 28 April 2021

Accepted: 20 May 2021

Published: 7 June 2021

Publisher's Note: MDPI stays neutral with regard to jurisdictional claims in published maps and institutional affiliations.

Copyright: (c) 2021 by the authors. Licensee MDPI, Basel, Switzerland. This article is an open access article distributed under the terms and conditions of the Creative Commons Attribution (CC BY) license (https:// creativecommons.org/licenses/by/ $4.0 /)$.
Abstract: Implementing solutions related to Industry 4.0 is a challenge for Polish industrial enterprises, regardless of size or affiliation to a larger, international organisation. The aim of this article is to examine the awareness, readiness and ability of these enterprises to meet this challenge. This study was conducted on a group of 60 randomly selected representatives of companies operating in Poland. A structured interview consisting of 32 questions, carried out using the English computer-assisted web interview (CAWI) method, was used to collect the data. Statistical differences between companies employing up to 249 people and companies employing at least 250 people were verified by the use of the nonparametric Mann-Whitney U test. Latent variables were also extracted, and the comparison was conducted using the independent samples from a Student's t-test. Regardless of the differences in responses between companies employing up to 249 employees and those employing 250 or more, the results showed an insufficient level of knowledge of technological solutions as well as a lack of awareness about supporting business development by means of specialised technology providers. Even though little awareness of the importance of Industry 4.0 solutions was identified, identifying key determinants for raising awareness of these solutions among companies operating in Poland may become not only the basis of further scientific research but also of a vital catalogue of activities that can be used to disseminate knowledge in this area. Both paths are extremely important for Polish enterprises. Practical implementation of Industry 4.0 measures particularly entails additional support for small and medium-sized enterprises (hereinafter SME) investment in technological, financial and human resources.

Keywords: Polish industrial enterprises; Industry 4.0; digitalisation; automatisation; IoT; 3D printing; Industry 4.0 readiness

\section{Introduction}

The global industrial landscape has changed profoundly in recent years. Efficiency, quality and flexibility are factors of production that determine not only financial results, but a company's survival in a highly competitive environment (Kovács 2020). For example, globalisation makes it possible for more efficient foreign companies to 'steal' a market from domestic companies (Lopes et al. 2021). Researchers have indicated that in order to meet such challenges, Polish businesses must be technologically and financially prepared (Vlčková et al. 2019) because the effectiveness of businesses depends on intense application of mechanical and human labour, especially in production where applications of machine labour are the most widespread (Inshakova et al. 2020). Strategies and processes that reduce operating costs (Genovese et al. 2014), however, must also be intelligent (Leitao et al. 2016) and autonomous (Bechtold et al. 2014), which means they must involve sustainable and renewable energy (Tesch da Silva et al. 2020). Research into the consequences of the total automatisation of human capital and artificial intelligence in Industry 4.0 production has shown that optimisation is achieved by means of proactive management and the 
stimulation of automatisation (Gashenko et al. 2020). Only a high level of automation and digitisation through the integration of machines, devices and production lines (Rashid and Tjahjono 2016) will allow a production plant (Anand and Ward 2004) to achieve the level of flexibility necessary to develop in a competitive global environment. In recent years, progress in production and technological processes has occurred alongside new global concepts known as the 'Fourth Industrial Revolution', also known as Industry 4.0, Smart Industry, Smart Manufacturing, Integrated Industry or the Industrial Internet of Things (Müller and Däschle 2018). Industry 4.0 should be placed alongside the three industrial revolutions that have taken place in recent centuries and represent major breakthroughs in production (Schmidt et al. 2015). The first industrial revolution, in the mid-18th century, was made possible by the invention of the steam engine in England. The second revolution marked the use of electricity and the beginning of mass production in the 19th century. The third revolution was brought about by automation in production processes. The fourth industrial revolution is based on the concept of continuous communication exchange not only between man and machine but directly between machines (Cooper and James 2009). It is worth emphasizing that technological changes progress dynamically. The first industrial revolution took centuries to develop. The second revolution took about 100 years. The third was introduced after 70 years, and 30-40 years later, Industry 4.0 was already being talked about. The technology is still progressing, and a fifth industrial revolution can be expected soon (Nowotarski and Paslawski 2017).

Implementation of the solutions related to Industry 4.0 are a challenge for Polish industrial enterprises, regardless of size or affiliation to a larger, international organisation. Therefore, the aim of this research is to present the level of awareness, readiness and ability that Polish enterprises need in order to identify what they need to know to increase their knowledge about Industry 4.0.

The purpose of this study, conducted on a group of 60 randomly selected representatives of industrial companies operating in Poland, is to examine the awareness, readiness and ability of enterprises to meet the challenge of implementing the solutions related to Industry 4.0. The results showed that it is possible to identify the implications of implementation, including the need for additional support to address technological, financial and human resources challenges.

This article is organised into six parts. Section 1 is an introduction; Section 2 is a literature review; Section 3 describes the research methodology; Section 4 presents the research results; Section 5 discusses the results; and Section 6 presents the main findings, theoretical and practical implications, study limitations and future lines of research.

\section{Literature Review}

Our highly competitive global business environment shapes Industry 4.0, which is likely to change the way entire industries design, plan, produce and deliver goods (Stock and Seliger 2016). The concept of Industry 4.0 first appeared as a result of the high-tech strategy for 2020 initiated by the German government in 2011 (Zhou et al. 2016) and is based on earlier concepts that evolved over the years (Kagermann 2015). Although technological innovations such as sensors and automation have been used by manufacturing companies for many years, limited connectivity and integration between the technologies used in manufacturing and enterprise systems (Veeramani et al. 1995) meant that their potential was not fully exploited (Li 2011; Naqvi et al. 2015). The Industry 4.0 concept includes the full use of a set of electronics and information technologies in the field of cyberphysical systems (CPS), intelligent robots, the Internet of Things (IoT), the Internet of Services (IoS), big data, augmented reality and digital manufacturing. These machines, devices, production lines and products can independently exchange information, initiate actions and control each other, thus enabling the creation of an intelligent production environment, which is crucial for the development of smarter production processes (Weyer et al. 2015; Vaníčková and Szczepańska-Woszczyna 2020). The Fourth Industrial Revolution connects the physical and digital worlds in a way that allows for improving the efficiency and 
effectiveness of industrial enterprises. This creates a huge set of economic and social opportunities, especially in the field of production technology and work organisation (Kagermann et al. 2013).

The key technologies framing the concept of Industry 4.0 are: intelligent sensors/ cyberphysical systems (CPS), the Internet of Things (IoT), the Internet of Services (IoS), big data, intelligent robots, augmented reality, 3D printing and fraud prevention and detection systems.

Intelligent sensors/cyberphysical systems (CPS) are mechanisms controlled or monitored by computer algorithms, tightly integrated with the Internet and its users and, as such, constitute a basic element of Industry 4.0 (Posada et al. 2015). In CPS, physical and software components are closely related, each operating on a different spatial and temporal scale, exhibiting many different behavioural modalities and interacting in many ways that change with context. Cyberphysical systems, by integrating the physical and computing environment (Lee et al. 2015), provide access to data and its processing (Monostori et al. 2016) and enable many innovative applications, including an innovative approach to the business model itself (Hellinge and Seeger 2011; Reischauer and Leitner 2016). Combining CPS with production allows for the horizontal and vertical integration of IT systems, transforming today's factories into Industry 4.0 factories. The Internet of Things (IoT) is a term that describes the combination of different technologies based on the exchange of data between physical things and the Internet. The technological development of the Internet made it possible to expand from connections between computers to the connection of intelligent objects (Kopetz 2011), enabling not only a collection of information but also an interaction with the environment through data exchange and running processes over the Internet. In industrial enterprises, we define IoT as an Internet connection between physical objects, people and systems located in the production hall. In the industrial environment, IoT has a huge impact on production and its automation, logistics and business process management (Atzori et al. 2010; Miorandi et al. 2012) through the use of breakthrough technologies such as sensors, actuators, data analysis, control systems and security mechanisms (Mourtzis et al. 2016). The production environment created in this way is called the Smart Factory (Shariatzadeha et al. 2016). In such a system, it is possible to interact between objects via the Internet, checking their status and all related information while accounting for security and privacy issues (Haller et al. 2008; Ashton 2009). According to Cardoso, IoT applications can be divided into three main pillars: process optimisation, resource optimisation and complex autonomous systems (Cardoso et al. 2008). The Internet of Services (IoS) emerged recently and is the equivalent of IoT in the service industry, providing the business and technical basis for creating business networks connecting service providers with customers. IoS enables the improvement of relations between suppliers, aggregators, service providers and customers by changing the way of providing services and raising their quality to a new, higher level (Schmidt et al. 2015; Pereira and Romero 2017). Big data is often seen as a catchword for data analysis, but it more so creates new products or services and responds to business changes as they occur (Davenport et al. 2012). There are a set of big data definitions that highlight different aspects of the concept. Some focus more on the variety aspect of data sources; others emphasise storage and analysis requirements. Wamba defines big data as a holistic approach to manage, process and analyse the five Vs (i.e., value, volume, variety, veracity and velocity) in order to create competitive advantages (Wamba et al. 2015). Intelligent robots in industry are robots that, thanks to the use of artificial intelligence, have the ability to learn and think logically and autonomously, performing more complex tasks with greater efficiency, without being dependent on programs written by people (Wang et al. 2016). Intelligent robots are also connected with modelling and simulation (M\&S), which is one of the basic tools for modelling future deterministic or unexpected stochastic events and defining the optimal scenario for operations. (Cservenák et al. 2014; Dudás 2010; Straka et al. 2014). Thanks to the integration of, among others, autonomous robots, IoT, big data, cloud computing and simulations of complex digital production systems (Gubán et al. 2017), factories can self-organise and optimise their own production activities, 
making them more competitive (Lee et al. 2015). Augmented reality (hereinafter AR) is defined as combining real and virtual objects in a real environment, interactively and in real time, to geometrically align virtual and real objects in the real world (Azuma et al. 2001). In order to keep up with the technology development of automated production systems (Romero et al. 2016), the workforce requires the implementation of solutions that increase the efficiency of labour. In response to these expectations, systems connecting the real world with the computer-generated world have been developed. A widely used solution is the use of AR applications in special training glasses that combine virtual and real working environments and assist the workers in the production process. Three-dimensional printing is one of the latest production technologies that allows for the generation of highly personalised products thanks to the combination of computers, machines and business processes (Zhong et al. 2015). Three-dimensional printing enables the production of highly customised products in small quantities while ensuring their quality and profitability. This ability can bring huge improvements in efficiency and productivity, allowing industrial enterprises to personalise the production processes. This makes it possible to implement flexible production strategies and business processes aimed at producing personalised mass products (Brecher et al. 2011). Fraud prevention and detection systems are used not only in the financial industry but also in the industrial enterprises. There are two basic types of these systems - fraud prevention systems (FPS) and fraud detection systems (FDS). FPS focuses primarily on preventing cyberattacks in computer systems, device networks and databases, using various types of encryption algorithms and firewalls. FDS replaces time-consuming, manual techniques for monitoring transactions and processes by aggregating data and knowledge in finance, economics and business. Data mining includes statistical techniques, mathematics, artificial intelligence and machine learning to identify fraud, indicate the likelihood of fraud or define new types of fraud (Abdallah et al. 2016).

Industry 4.0 is a huge set of economic and social opportunities that creates new business models tailored to the needs of customers, allowing for the increase of production flexibility and ultimately international competitiveness, especially important in an industrialised country such as Poland. The globalisation of economies allows no room for a technological gap both between corporate branches in different locations internationally and between large enterprises and SMEs cooperating with them locally, which are commonly perceived as important elements in stimulating and stabilising global economic growth (Mokhtar et al. 2020; Szczepańska-Woszczyna and Kurowska-Pysz 2016). In order to fully use the possibilities of Industry 4.0 in production plants located in Poland, the implementation should also take place in SMEs cooperating with these plants.

In relation to the impact of Industry 4.0, according to research by Vrchota and Pech, $65.7 \%$ of companies in the Czech Republic have already started implementing Industry 4.0 (Vrchota and Pech 2019). According to the analysis by Ganzarain and Errasti on a representative sample of SMEs in the Basque Country, only a few companies use holistic Industry 4.0 methodology. (Ganzarain and Errasti 2016). The review of nine studies of German manufacturing enterprises by Lutz Sommer showed that there is an awareness concerning the relevance of Industry 4.0. The readiness and the capability to meet this challenge depends strongly on the size of an enterprise. The smaller the SME, the higher the risk that they will become victims instead of beneficiaries of this revolution (Sommer 2015). Studies in Germany have shown that between $68 \%$ of companies (Schulze 2014) and $82 \%$ of companies (Sommer 2015) are ready to implement Industry 4.0 solutions. The results of the benchmark study by Machado et al. indicates that the majority of Swedish companies are at an overall level similar to that of German manufacturing industries. The results indicate that companies need to increase efforts on training and identifying key competences (Machado et al. 2019).

Based on the above literature, we hypothesise the differences in the level of knowledge of Polish industrial enterprises of Industry 4.0 solutions depending on their size. Hence, the hypothesis concerning the differences in the current level of knowledge is as follows: 
Hypothesis 1. The level of knowledge of Polish industrial enterprises in the field of Industry 4.0 varies depending on their size.

The question is how well prepared the industrial plants (including SMEs) located in Poland are to face the Fourth Industrial Revolution. The question of what qualifications are necessary for the proper implementation of Industry 4.0 solutions should also be asked. Similar questions have already been asked by Polish researchers who, based on the analysis of secondary sources, indicated the low maturity of domestic small- and medium-sized enterprises to implement Industry 4.0 solutions (Ślusarczyk and Pypłacz 2020).

In view of the above, researchers ask whether enterprises in Poland are able to effectively benefit from the achievements of the Fourth Industrial Revolution, or whether they will become its victims due to the lack of the ability to adapt.

\section{Research Methodology}

The study was conducted to examine the level of awareness, readiness and ability of enterprises located in Poland to implement Industry 4.0 solutions. To collect the data, a structured interview was used, carried out using the CAWI (computer-assisted web interview) method, consisting of 32 questions divided into research areas in the field of the technological competences of the respondents and suppliers of Industry 4.0 solutions. Some of the questions were modelled on the research conducted by Ślusarczyk (2018) and Ślusarczyk and Pypłacz (2020). Based on abovementioned studies as well as considering our experience, it was decided to determine answers to the following research questions:

- To what extent is the Industry 4.0 concept known to representatives of industrial enterprises operating in Poland?

- What technological solutions covering the Fourth Industrial Revolution are known to representatives of industrial enterprises operating in Poland?

- What barriers to implementation of Industry 4.0 solutions are known to representatives of industrial enterprises operating in Poland?

- What benefits of implementing Industry 4.0 solutions are known to representatives of industrial enterprises operating in Poland?

- Who should be involved in the decision-making process to implement Industry 4.0 solutions?

- Who should be responsible for the implementation of Industry 4.0 solutions?

- Do the development strategies of enterprises operating in Poland include the implementation of Industry 4.0 solutions in the next 5 years?

- In your opinion, what elements could support the decision-making process regarding the implementation of Industry 4.0 solutions in the enterprise and to what extent could those elements support it?

- To what extent do smaller companies employing up to 249 employees differ from companies employing at least 250 employees in terms of: perceived technological competences; barriers to implementing Industry 4.0 solutions; benefits in implementing Industry 4.0 solutions; degree of business unit responsibility for the implementation of Industry 4.0 solutions; degree of support for the decision-making process to implement Industry 4.0 solutions?

The interview was conducted in January 2021 on a group of 60 randomly selected industrial companies representing industries in accordance with the leading profile of the company's activity according to the Statistical Classification of Economic Activities used in the European Community: division C Industrial Processing of the European Classification of Activities (EKD). Rev. 2 (NACE Rev. 2-Statistical classification of economic activities. In 2002, a major revision of NACE was launched. The Regulation establishing NACE Rev. 2 is to be used, in general, for statistics referring to economic activities performed as from 1 January 2008 onwards), Table 1 below. 
Table 1. Division of the surveyed companies by Statistical Classification of Economic Activities (NACE Rev. 2).

\begin{tabular}{|c|c|c|c|}
\hline \multirow{2}{*}{ Classification of Economic Activities } & \multirow{2}{*}{ Classification Code } & \multicolumn{2}{|c|}{ Number of Companies } \\
\hline & & 1-249 & $250+$ \\
\hline Manufacture of food products & 10 & 0 & 3 \\
\hline $\begin{array}{l}\text { Manufacture of machinery and } \\
\text { equipment n.e.c. }\end{array}$ & 28 & 1 & 3 \\
\hline Manufacture of furniture & 31 & 2 & 1 \\
\hline $\begin{array}{l}\text { Manufacture of fabricated metal } \\
\text { products, except machinery and } \\
\text { equipment }\end{array}$ & 25 & 6 & 3 \\
\hline $\begin{array}{l}\text { Manufacture of paper and paper } \\
\text { products }\end{array}$ & 17 & 4 & 3 \\
\hline $\begin{array}{l}\text { Manufacture of motor vehicles, trailers } \\
\text { and semi-trailers }\end{array}$ & 29 & 2 & 17 \\
\hline $\begin{array}{l}\text { Manufacture of other transport } \\
\text { equipment }\end{array}$ & 30 & 0 & 2 \\
\hline $\begin{array}{l}\text { Manufacture of other nonmetallic } \\
\text { mineral products }\end{array}$ & 23 & 6 & 0 \\
\hline \multirow[t]{2}{*}{ Other manufacturing } & 32 & 6 & 1 \\
\hline & $\begin{array}{l}\text { Total number of } \\
\text { companies: }\end{array}$ & 27 & 33 \\
\hline
\end{tabular}

At the request of the representatives of the respondent companies, the names of the surveyed companies were not disclosed.

In the analysed enterprises, the questions were answered by owners/directors, senior and middle-level managers, R\&D departments and plant management as well as specialists in the field of technical service. The division of respondents, depending on the size of the company, is presented in Figure 1 below.

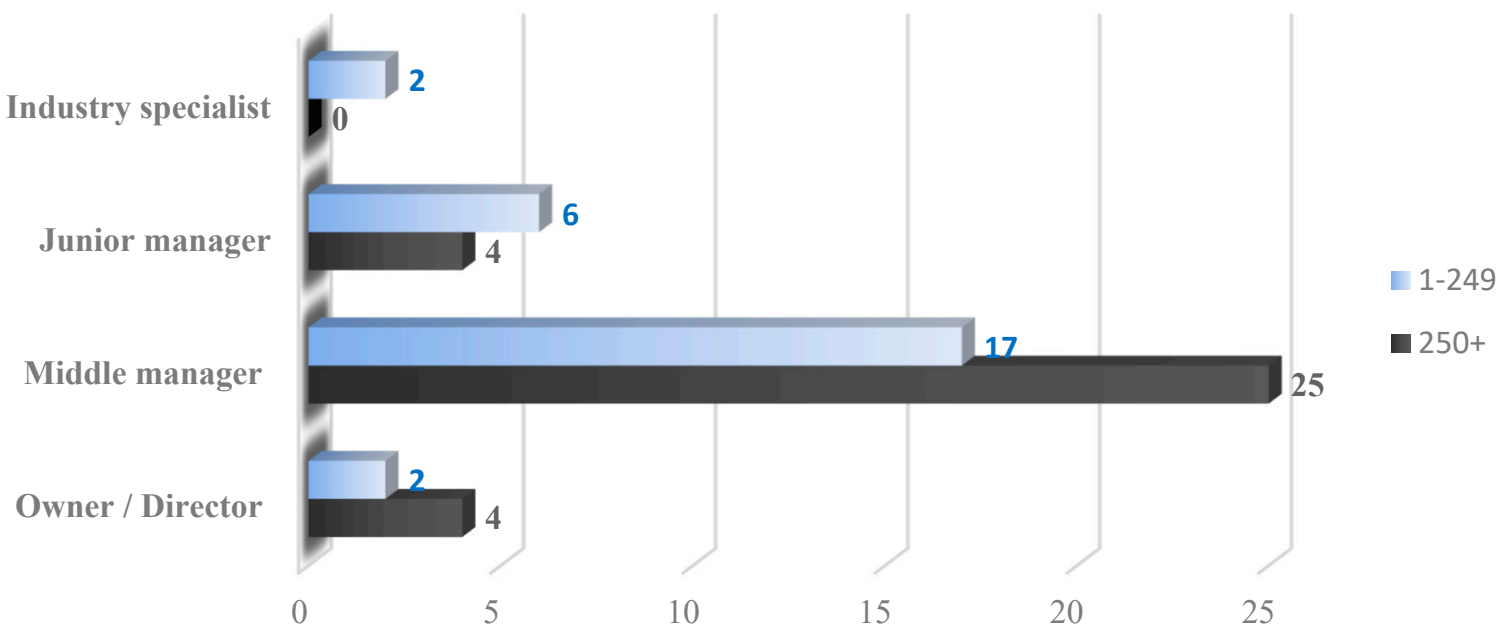

Figure 1. Division of respondents according to their position.

- $\quad$ Owner/Director (6);

- $\quad$ Middle manager (42);

- Junior manager (10);

- For two (2) surveys, industry specialists replied. 
Out of 60 companies included in the study, 27 companies (45.0\%) employed up to 249 employers, and 33 companies (55.0\%) employed at least 250 employers.

The survey consisted of 32 questions, was divided into areas according to the scope of the research described above and was conducted by using the CAWI method. The answers were given on a five-point Likert scale, in which different grades had the following meanings: $1=$ no impact $/$ knowledge; $2=$ low impact $/$ knowledge; $3=$ neutral impact/knowledge; $4=$ high impact/knowledge; and $5=$ very high impact/knowledge.

Taking into account the fact that the decision to implement new technological solutions is influenced by the knowledge of decision makers, it was examined whether this knowledge depends on the size of the company and the position of the decision maker in the company. This is due to the fact that enterprises-in particular SMEs-have limited resources, which significantly hinders their decision-making process or causes wrong decisions. (Edvardsson and Durst 2013). Moreover, the ability of enterprises to develop and innovate depends on the knowledge and vision of their managers (Camisón-Haba et al. 2019).

The Likert scales are ordinal scales unless the results are summed up measuring the underlying latent construct. Therefore, statistical differences between companies employing up to 249 participants and companies employing at least 250 participants were verified with the use of the Mann-Whitney $U$ test, which is a nonparametric statistical test allowing for comparisons between two independent groups of observations in terms of variables measured on ordinal scales. The Likert scales were also analysed with the use of principal component analysis. The extracted factors were also compared between companies employing up to 249 participants and companies employing at least 250 participants.

\section{Research Results}

The concept of the Fourth Industrial Revolution, especially under the name of Industry 4.0, is widely discussed. The definition of Industry 4.0 remains open. Despite growing interest in the subject, there is still no clear vision of its paradigm. Industry 4.0 can be understood as a common term for technologies and concepts that cover the entire value chain of an organisation (Hermann et al. 2016). The new industrial paradigm also includes the development of intelligent environments that are able to connect the real and virtual worlds by integrating devices, machines and production lines that control each other autonomously (Weyer et al. 2015). From a technical point of view, the industrial paradigm can be described as increased communication creating a value chain through the digitisation and automation of the production environment (Oesterreich and Teuteberg 2016). All of these views are reflected in respondents' answers. Moreover, despite the fact that all respondents have heard both about the concept itself and about selected technological solutions (Table 2 below), most companies are not aware of the challenges posed by the willingness to implement Industry 4.0 solutions.

The results of the analysis and the conducted empirical research showed an insufficient state of knowledge in the field of technological solutions, as well as insufficient awareness of the possibilities of support in the field of enterprise development by technology suppliers. At the time of the survey, only five companies had implemented Industry 4.0 technologies, which constitutes $8.33 \%$ of the surveyed enterprises.

The results of the assessment of the knowledge of the respondents in the field of innovative technologies are presented in Table 2 below. The strength of the knowledge of the respondents about the technology was assessed using a five-point Likert scale, in which different ratings had the following meaning: 1 = lack of knowledge; $2=$ low level of knowledge; $3=$ neutral level of knowledge; $4=$ high level of knowledge; and $5=\mathrm{a}$ significant level of knowledge.

The research results indicate that the most well-known technological solutions among the respondents are: intelligent robots, 3D printing, intelligent sensors and the widely understood use of IoT. The least knowledge was shown by the respondents in the field of advanced customer interaction technology as well fraud detection. Further analysis 
of the answers also showed that regardless of the size of the company, the industry in which it operates or the position held by the respondent, over $78 \%$ of respondents do not know what technology providers offer in the field of Industry 4.0. Less than $22 \%$ of the respondents had contact with providers of advanced technological solutions, but they were not able to provide details. Importantly, among 60 respondents, when asked about the willingness to cooperate with technology suppliers in the field of Industry 4.0, only one company expressed interest.

Table 2. Assessment of the respondents' knowledge about innovative technologies on the Likert scale.

\begin{tabular}{lccccc}
\hline \multicolumn{1}{c}{ Likert Scale: } & $\mathbf{1}$ & $\mathbf{2}$ & $\mathbf{3}$ & $\mathbf{4}$ & $\mathbf{5}$ \\
\hline \multicolumn{1}{c}{ Technological Competences: } & & & & & \\
\hline Intelligent robots & 13 & 9 & 7 & 3 & 1 \\
\hline Augmented reality & 16 & 14 & 1 & 2 & 0 \\
\hline 3D printing & 7 & 12 & 7 & 5 & 2 \\
\hline Geolocation & 26 & 2 & 3 & 1 & 1 \\
\hline Intelligent sensors & 9 & 5 & 10 & 6 & 3 \\
\hline IoT & 9 & 12 & 9 & 3 & 0 \\
\hline Cloud computing & 21 & 9 & 0 & 3 & 0 \\
\hline Big Data & 18 & 10 & 3 & 2 & 0 \\
\hline Mobile devices & 24 & 4 & 2 & 1 & 2 \\
\hline Advanced interaction with customers & 30 & 1 & 0 & 1 & 1 \\
\hline Fraud detection & 32 & 1 & 0 & 0 & 0 \\
\hline IoT-Internet of Things. & & & & &
\end{tabular}

IoT-Internet of Things.

Table 3 presents mean values acquired from the Likert scales regarding the respondents' knowledge about innovative technologies in companies employing up to 249 participants and in companies employing at least 250 participants with the values of the Mann-Whitney U test.

Table 3. Assessment of the respondents' knowledge about innovative technologies in companies employing up to 249 participants and in companies employing at least 250 participants.

\begin{tabular}{lllll}
\hline \multicolumn{1}{c}{ Number of Employees: } & $\mathbf{1 - 2 4 9}$ & $\mathbf{2 5 0 +}$ & $\mathrm{U}$ & $\boldsymbol{p}$ \\
\hline \multicolumn{1}{c}{ Technological Competences: } & & & & \\
\hline Intelligent robots & 1.96 & 2.21 & 361.50 & 0.186 \\
\hline Augmented reality & 1.85 & 1.94 & 414.50 & 0.619 \\
\hline 3D printing & 2.48 & 2.48 & 425.00 & 0.751 \\
\hline Geolocation & 1.67 & 1.48 & 420.00 & 0.645 \\
\hline Intelligent sensors & 2.44 & 3.00 & 326.50 & 0.070 \\
\hline IoT & 2.19 & 2.52 & 357.50 & 0.173 \\
\hline Cloud computing & 2.04 & 1.52 & 308.00 & 0.025 \\
\hline Big Data & 1.78 & 1.58 & 423.50 & 0.713 \\
\hline Mobile devices & 1.93 & 1.39 & 377.00 & 0.190 \\
\hline Advanced interaction with customers & 1.48 & 1.12 & 347.00 & 0.013 \\
\hline Fraud detection & 1.44 & 1.00 & 346.50 & 0.005 \\
\hline U-Valus & & &
\end{tabular}

U-values of the Mann-Whitney U test; $p$-statistical significance. 
The assessment of technological competencies regarding cloud computing, advanced interaction with customers and fraud detection was significantly higher in companies employing up to 249 employees.

The results on the Likert scales were also analysed with the use of principal component analysis with oblique Oblimin rotation. The acquired scree plot is depicted in Figure 2.

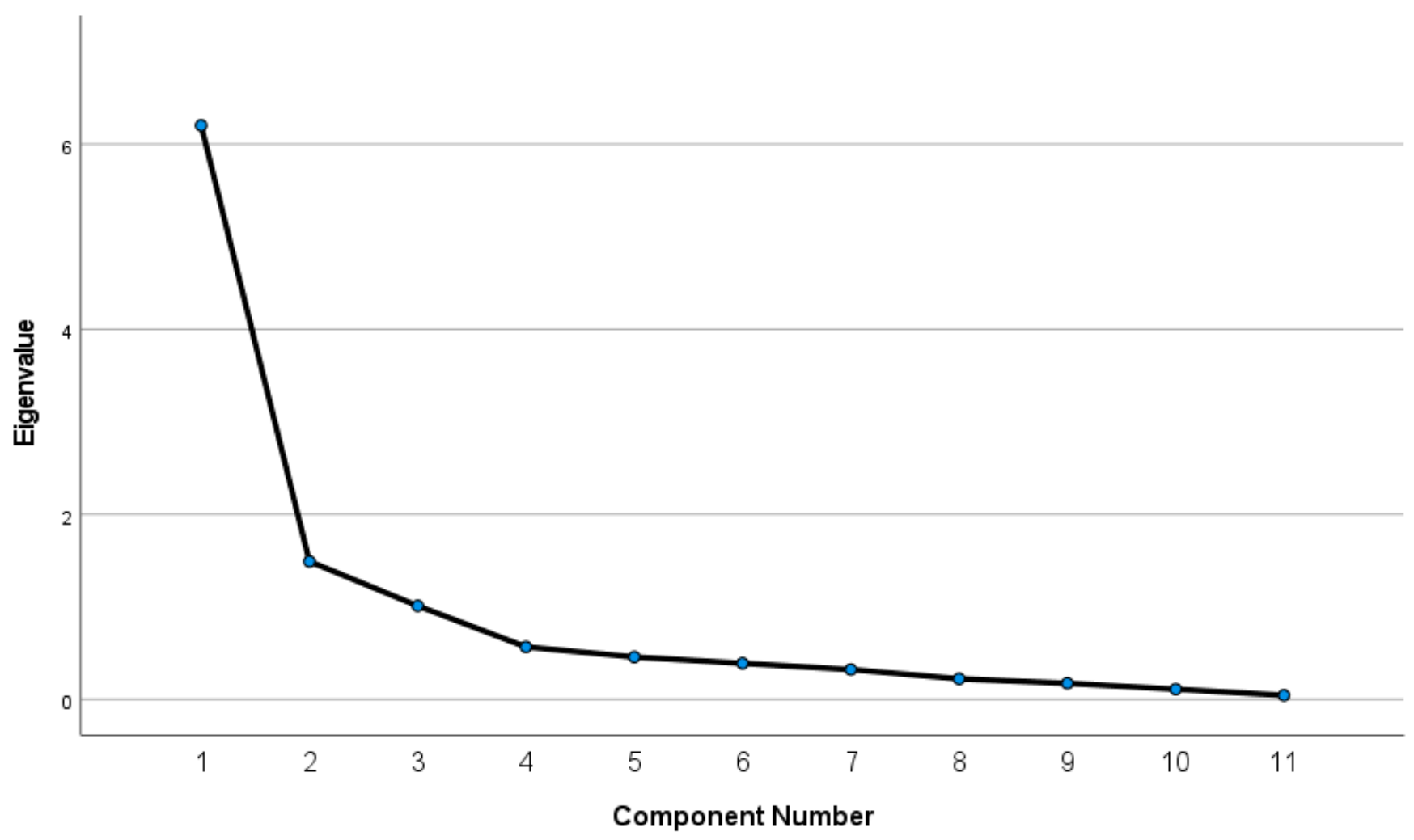

Figure 2. Scree plot in the principal component analysis regarding technological competencies.

Based on the Kaiser criterion, three components were extracted. Table 4 presents factor loadings in a pattern matrix. The values lower than 0.4 were suppressed for clarity.

Based on the factor loadings, two factors were extracted. The third component was discarded because it did not contain items with factor loadings higher than the factor loadings on the other two factors. Taking the items' contents into consideration, the first factor was named 'Human-based competencies', and the second factor was named 'Equipment-based competencies'. According to the values of the independent samples t-test, there were no statistically significant differences between companies employing 1-249 workers and companies employing at least 250 workers regarding human-based competencies, $t(38.93)=1.12, p>0.05$, or regarding equipment competencies, $t(58)=$ $-1.46, p>0.05$.

As indicated by the results of the research presented in Table 5 below, the respondents pointed out the following aspects as the greatest barriers in the implementation of Industry 4.0 solutions: 'Problems with appropriately qualified staff' (44 respondents) and 'Problems with technical integration' (43 respondents). The barriers with the least impact on the implementation of Industry 4.0 solutions were considered by the respondents as: 'Insufficient financial resources' (15 respondents) and 'Resistance in the organisation against implementing Industry 4.0 solutions' (17 respondents). 
Table 4. Pattern matrix acquired in the principal component analysis regarding technological competencies.

\begin{tabular}{cccc}
\hline Item & $\begin{array}{c}\text { Factor 1 } \\
\text { Human-Based } \\
\text { Competencies }\end{array}$ & $\begin{array}{c}\text { Factor 2 } \\
\text { Equipment-Based } \\
\text { Competencies }\end{array}$ & Factor 3 \\
\hline $\begin{array}{c}\text { 9. Mobile devices } \\
\text { 10. Advanced interaction with } \\
\text { customers }\end{array}$ & 0.99 & & \\
\hline 8. Big Data & 0.96 & \\
\hline 7. Cloud computing & 0.84 & & \\
\hline 11. Fraud detection & 0.76 & \\
\hline 4. Geolocation & 0.73 & \\
\hline 3. 3D printing & 0.72 & -0.45 \\
\hline 1. Intelligent robots & 0.68 & \\
\hline 6. IoT & 0.58 & 0.53 \\
\hline 5. Intelligent sensors & & 0.79 \\
\hline 2. Augmented reality & & 0.78 & \\
\hline
\end{tabular}

Table 5. Barriers to implementing Industry 4.0 solutions in the enterprise.

\begin{tabular}{cc}
\hline Barriers to Implementing Industry 4.0 Solutions in the Enterprise: & No. of Respondents \\
\hline Problems with appropriately qualified staff & 44 \\
\hline Insufficient financial resources & 15 \\
\hline Standardisation problems & 21 \\
\hline Concerns about data security and ownership & 23 \\
\hline Problems with technical integration & 43 \\
\hline $\begin{array}{c}\text { Lack of competences and activities related to implementation planning } \\
\text { (no set decision makers and persons responsible for implementation) }\end{array}$ & 23 \\
\hline Organisational resistance against the implementation of Industry 4.0 \\
solutions
\end{tabular}

Table 6 presents mean values acquired from the Likert scales regarding barriers to implementing Industry 4.0 solutions in companies employing up to 249 participants and in companies employing at least 250 participants with the values of the Mann-Whitney U test.

The assessment of barriers regarding standardisation problems was significantly higher in companies employing at least 250 employees.

The results on the Likert scales were also analysed with the use of principal component analysis with oblique Oblimin rotation. The acquired scree plot is depicted in Figure 3. 
Table 6. Assessment of barriers to implementing Industry 4.0 solutions in the enterprise in companies employing up to 249 participants and in companies employing at least 250 participants.

\begin{tabular}{|c|c|c|c|c|}
\hline $\begin{array}{l}\text { Number of Employees: } \\
\text { Barriers to Implementing Industry 4.0 Solutions in the Enterprise: }\end{array}$ & $1-249$ & $250+$ & $\mathbf{U}$ & $p$ \\
\hline Problems with appropriately qualified staff & 0.63 & 0.82 & 361.50 & 0.103 \\
\hline Insufficient financial resources & 0.30 & 0.21 & 408.00 & 0.458 \\
\hline Standardisation problems & 0.07 & 0.58 & 222.00 & 0.001 \\
\hline Concerns about data security and ownership & 0.33 & 0.42 & 405.00 & 0.475 \\
\hline Problems with technical integration & 0.67 & 0.76 & 405.00 & 0.441 \\
\hline Problems with coordinating implementation across departments & 0.52 & 0.27 & 336.00 & 0.053 \\
\hline $\begin{array}{l}\text { Lack of competences and activities related to implementation } \\
\text { planning (no set decision makers and persons responsible for } \\
\text { implementation) }\end{array}$ & 0.37 & 0.36 & 442.50 & 0.957 \\
\hline $\begin{array}{l}\text { Organisational resistance against the implementation of Industry } 4.0 \\
\text { solutions }\end{array}$ & 0.37 & 0.21 & 375.00 & 0.180 \\
\hline
\end{tabular}

U-values of the Mann-Whitney U test; $p$-statistical significance.

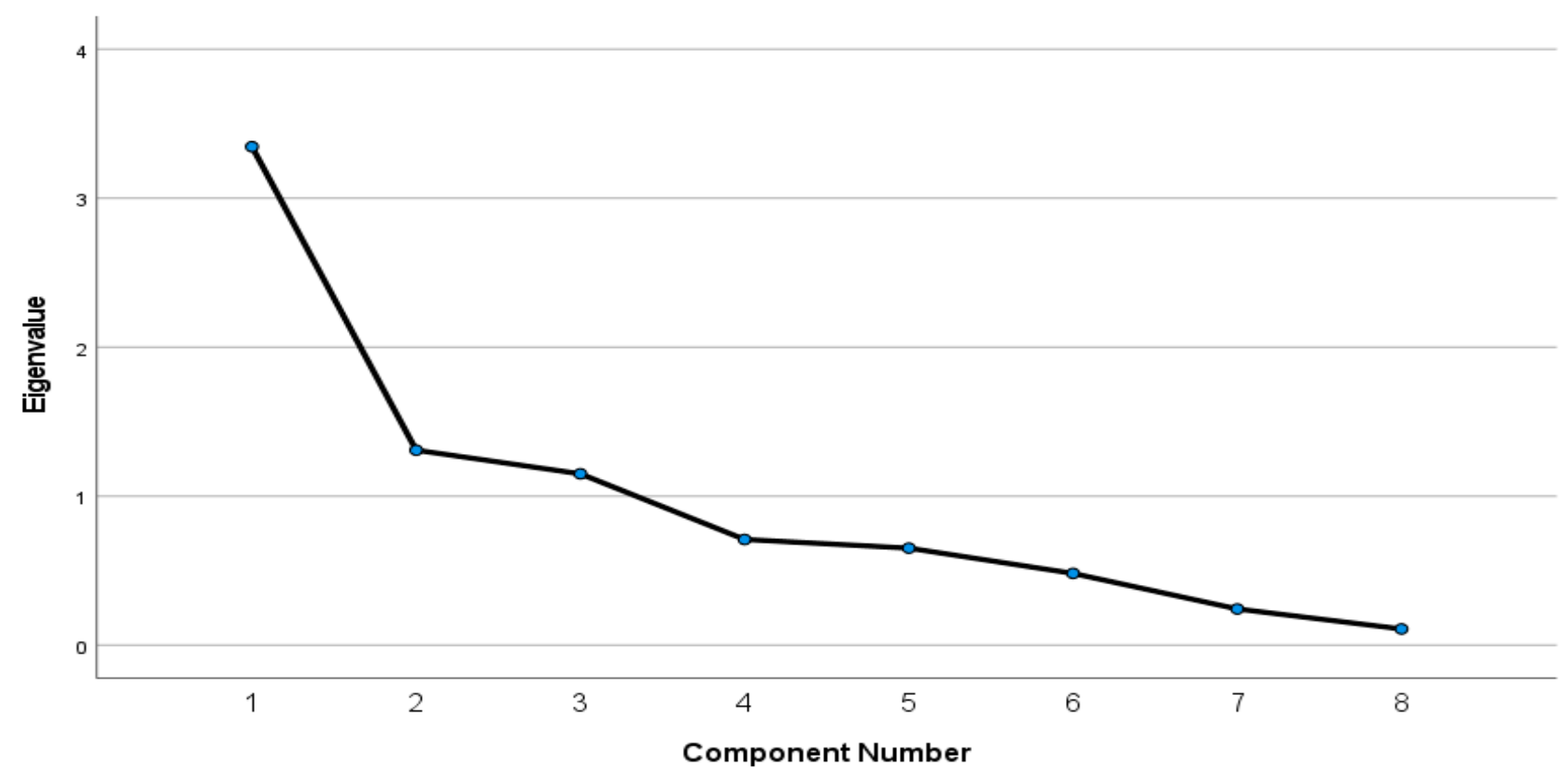

Figure 3. Scree plot in the principal component analysis regarding barriers to implementing Industry 4.0 solutions.

Based on the Kaiser criterion, three components were extracted. Table 7 presents factor loadings in a pattern matrix. The values lower than 0.4 were suppressed for clarity.

Based on the factor loadings, two factors were extracted. The second component was discarded because it was based only on two items. Taking the items' contents into consideration, the first factor was named 'Organisational barriers' and the third factor was named 'Implementation barriers'. According to the values of the independent samples t-test, there were no statistically significant differences between companies employing 1-249 workers and companies employing at least 250 workers regarding organisational barriers, $t(58)=-0.50, p>0.05$, and regarding implementation barriers, $t(58)=1.69$, $p>0.05$. 
Table 7. Pattern matrix acquired in the principal component analysis regarding barriers to implementing Industry 4.0 solutions.

\begin{tabular}{|c|c|c|c|}
\hline Item & $\begin{array}{l}\text { Factor } 1 \\
\text { Organisational } \\
\text { Barriers }\end{array}$ & Factor 2 & $\begin{array}{c}\text { Factor } 3 \\
\text { Implementation Barriers }\end{array}$ \\
\hline Problems with appropriately qualified staff P1 & 0.85 & & \\
\hline $\begin{array}{l}\text { Organisational resistance against the } \\
\text { implementation of Industry } 4.0 \text { solutions P8 }\end{array}$ & -0.83 & & \\
\hline Problems with technical integration & 0.72 & & \\
\hline Standardisation problems & 0.72 & & \\
\hline Concerns about data security and ownership & -0.58 & & \\
\hline Insufficient financial resources & & -0.81 & 0.48 \\
\hline $\begin{array}{l}\text { Problems with coordinating implementation across } \\
\text { departments }\end{array}$ & -0.56 & 0.63 & 0.41 \\
\hline $\begin{array}{l}\text { Lack of competences and activities related to } \\
\text { implementation planning (no set decision makers } \\
\text { and persons responsible for implementation) }\end{array}$ & 0.50 & & 0.66 \\
\hline
\end{tabular}

According to the given responses (Table 8 below), the respondents considered the greatest benefits of implementing Industry 4.0 solutions as: 'Optimisation of automation processes' (53 respondents), 'Increasing the efficiency of energy consumption" (44 respondents), 'Increasing product quality '(38 respondents) and 'Increasing productivity' (37 respondents). The smallest benefits from the implementation of Industry 4.0 solutions were considered by the respondents as: 'Support for the decision-making process' (9 respondents) and 'Support for sustainable development' (10 respondents).

Table 8. Benefits in implementing Industry 4.0 solutions known to the respondents.

\begin{tabular}{cc}
\hline $\begin{array}{c}\text { Benefits of Implementing Industry } 4.0 \text { Solutions in the } \\
\text { Enterprise }\end{array}$ & No. of Respondents \\
\hline $\begin{array}{c}\text { Better adaptation of products to customer needs } \\
\text { Optimisation of automation processes }\end{array}$ & 26 \\
\hline Increasing the efficiency of energy consumption & 43 \\
\hline Product quality improvement & 38 \\
\hline Support for the decision-making process & 9 \\
\hline Reduction of operating costs & 32 \\
\hline Increase your productivity & 37 \\
\hline Support for sustainable development & 10 \\
\hline Improving control processes & 15 \\
\hline Securing know-how through the use of machines and \\
automation
\end{tabular}

Table 9 presents mean values acquired from the Likert scales regarding benefits in implementing Industry 4.0 solutions in companies employing up to 249 participants and in companies employing at least 250 participants with the values of the Mann-Whitney U test. 
Table 9. Assessment of benefits to implementing Industry 4.0 solutions in the enterprise in companies employing up to 249 participants and in companies employing at least 250 participants.

\begin{tabular}{|c|c|c|c|c|}
\hline $\begin{array}{l}\text { Number of Employees: } \\
\text { Benefits of Implementing Industry } 4.0 \text { Solutions in the Enterprise: }\end{array}$ & $1-249$ & $250+$ & $\mathbf{U}$ & $p$ \\
\hline Better adaptation of products to customer needs & 0.52 & 0.36 & 376.50 & 0.232 \\
\hline Optimisation of automation processes & 0.78 & 0.97 & 360.00 & 0.022 \\
\hline Increasing the efficiency of energy consumption & 0.81 & 0.67 & 379.50 & 0.200 \\
\hline Product quality improvement & 0.81 & 0.48 & 298.50 & 0.009 \\
\hline Support for the decision-making process & 0.15 & 0.15 & 444.00 & 0.971 \\
\hline Reduction of operating costs & 0.56 & 0.52 & 427.50 & 0.757 \\
\hline Increase your productivity & 0.63 & 0.61 & 435.00 & 0.853 \\
\hline Support for sustainable development & 0.19 & 0.15 & 430.50 & 0.730 \\
\hline Improving control processes & 0.22 & 0.27 & 423.00 & 0.656 \\
\hline Securing know-how through the use of machines and automation & 0.67 & 0.42 & 337.50 & 0.063 \\
\hline
\end{tabular}

U-values of the Mann-Whitney U test; $p$-statistical significance.

The assessment of the optimisation of automation processes was significantly higher in companies employing at least 250 employees. The assessment of product quality improvement was significantly higher in companies employing up to 249 employees.

The results from the Likert scales were also analysed with the use of principal component analysis with oblique Oblimin rotation. The acquired scree plot is depicted in Figure 4.

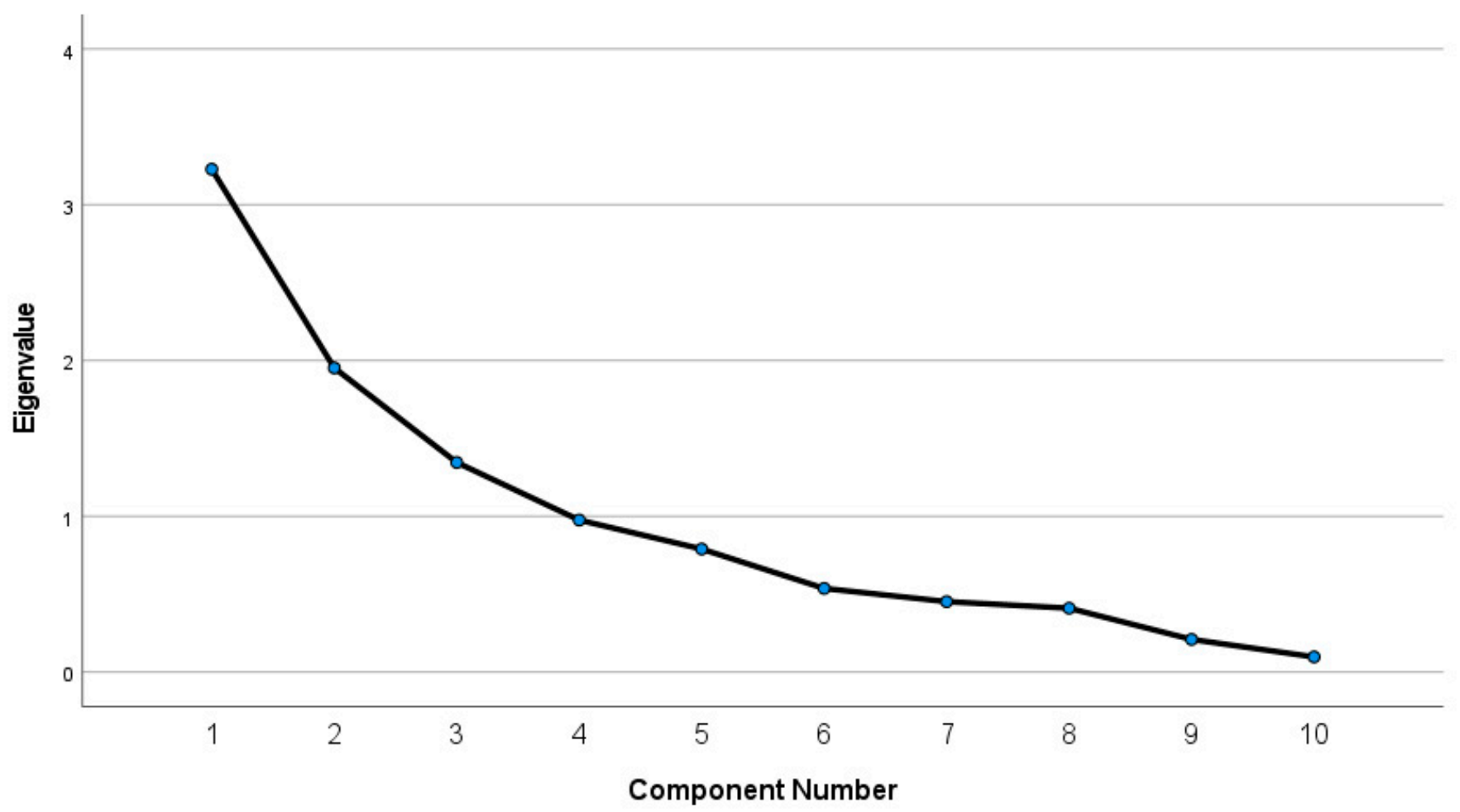

Figure 4. Scree plot in the principal component analysis regarding benefits of implementing Industry 4.0 solutions.

Based on the Kaiser criterion, three components were extracted. Table 10 presents factor loadings in a pattern matrix. The values lower than 0.4 were suppressed for clarity. 
Table 10. Pattern matrix acquired in the principal component analysis regarding benefits of implementing Industry 4.0 solutions.

\begin{tabular}{ccc}
\hline Item & $\begin{array}{c}\text { Factor 1 } \\
\text { Product- } \\
\text { Based Benefits }\end{array}$ & $\begin{array}{c}\text { Factor 2 } \\
\text { Optimisation-Based Benefits }\end{array}$ \\
\hline $\begin{array}{c}\text { Securing know-how through the use of machines } \\
\text { and automation }\end{array}$ & 0.91 & 0.86 \\
\hline Product quality improvement & 0.84 & 0.79 \\
\hline Better adaptation of products to customer needs & 0.67 \\
\hline Support for the decision-making process & 0.62 \\
\hline Reduction of operating costs & 0.57 \\
\hline Improving control processes & -0.54 \\
\hline Support for sustainable development & 0.42 & 0.89 \\
\hline Optimisation of automation processes & & \\
\hline Increase your productivity & & \\
\hline
\end{tabular}

Based on the factor loadings, two factors were extracted. Taking the items' contents into consideration, the first factor was named 'Product-based benefits' and the second factor was named 'Optimisation-based benefits'. The third factor was discarded because it was based on only two items. According to the values of the independent samples t-test, there were statistically significant differences between companies employing 1-249 workers and companies employing at least 250 workers regarding both product-based benefits, $t(57.98)=2.20, p<0.05$, and optimisation-based benefits, $t(58)=-2.08, p<0.05$. The mean value of product-based benefits was higher in smaller companies, while that of optimisation-based benefits was higher in larger companies (see Figure 5).

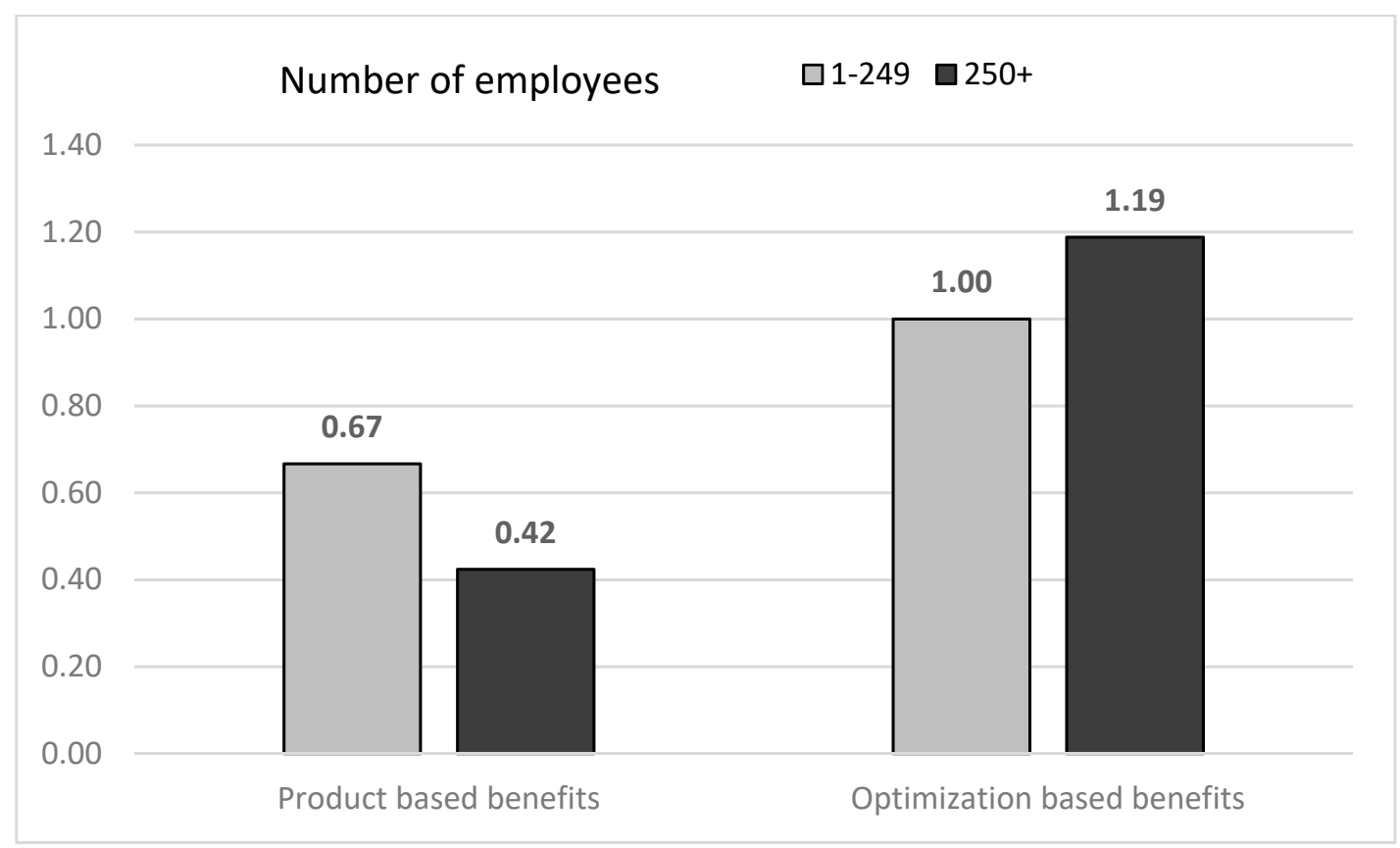

Figure 5. Mean values of product-based benefits and optimisation-based benefits in companies employing 1-249 workers and in companies employing at least 250 workers. 
The research results (Table 11 below) showed that according to the respondents, the following persons should be involved in the decision-making process, in particular: the Management Board (25 respondents) and the head of the department concerned with the given solution (23 respondents). All respondents indicated at least one person/department who, according to the respondents, should be involved in the decision-making process on the implementation of Industry 4.0 solutions.

Table 11. A unit involved in the decision-making process to implement Industry 4.0 solutions.

\begin{tabular}{cc}
\hline An Entity Involved in the Decision-Making Process & No. of Respondents \\
\hline Management Board & 25 \\
\hline Head of the department to which a given solution applies & 23 \\
\hline IT Department & 17 \\
\hline Cross-section implementation team & 7 \\
\hline I do not know & 0 \\
\hline
\end{tabular}

The units and the degree of their responsibility for the implementation of Industry 4.0 solutions are presented in Table 12 below. Questioned as to who should be responsible for the implementation of Industry 4.0 solutions and to what extent they should be responsible, the respondents made an assessment using a five-point Likert scale, in which different assessments had the following meanings: $1=$ bears no responsibility; 2 = has little responsibility; 3 = indicates a neutral level of responsibility; $4=$ means a high level of responsibility; 5 = bears significant responsibility. Thirty-seven respondents marked the answer 'Other' without indicating specific units responsible for the implementation, making the answer dependent on the implemented technology.

Table 12. The unit and the degree of its responsibility for the implementation of Industry 4.0 solutions.

\begin{tabular}{|c|c|c|c|c|c|}
\hline $\begin{array}{l}\text { Likert Scale: } \\
\text { Unit Responsible for the Implementation Process }\end{array}$ & 1 & 2 & 3 & 4 & 5 \\
\hline Management Board & 10 & 9 & 9 & 16 & 16 \\
\hline Head of the department to which a given solution applies & 1 & 1 & 20 & 28 & 10 \\
\hline IT Department & 22 & 9 & 8 & 17 & 4 \\
\hline Cross-section implementation team & 28 & 1 & 11 & 7 & 13 \\
\hline I do not know & 37 & & & & \\
\hline
\end{tabular}

Table 13 presents the mean values acquired from the Likert scales regarding the degree of unit responsibility for the implementation of Industry 4.0 solutions in companies employing up to 249 participants and in companies employing at least 250 participants with the values of the Mann-Whitney U test.

The assessment of management board responsibility was significantly lower in companies employing at least 250 employees.

The results from the Likert scales were also analysed with the use of principal component analysis with oblique Oblimin rotation. The acquired scree plot, which shows the eigenvalues on the $y$-axis and the number of factors on the $x$-axis and is used to determine the number of factors to retain is depicted on Figure 6. 
Table 13. Assessment of degree of unit responsibility for the implementation of Industry 4.0 solutions in companies employing up to 249 participants and in companies employing at least 250 participants.

\begin{tabular}{ccccc}
\hline $\begin{array}{c}\text { Number of Employees: } \\
\text { Unit Responsible for the } \\
\text { Implementation Process: }\end{array}$ & $\mathbf{1 - 2 4 9}$ & $\mathbf{2 5 0 +}$ & $\mathrm{U}$ & $\boldsymbol{p}$ \\
\hline $\begin{array}{c}\text { Management Board } \\
\text { Head of the department to which a given } \\
\text { solution applies }\end{array}$ & 3.85 & 2.88 & 282.00 & 0.013 \\
\hline $\begin{array}{c}\text { IT Department } \\
\text { IT }\end{array}$ & 2.37 & 3.70 & 397.00 & 0.436 \\
\hline Cross-section implementation team & 2.70 & 2.67 & 400.00 & 0.481 \\
\hline I do not know & 1.04 & 1.00 & 412.50 & 0.601 \\
\hline
\end{tabular}

U-values of the Mann-Whitney U test; $p$-statistical significance.

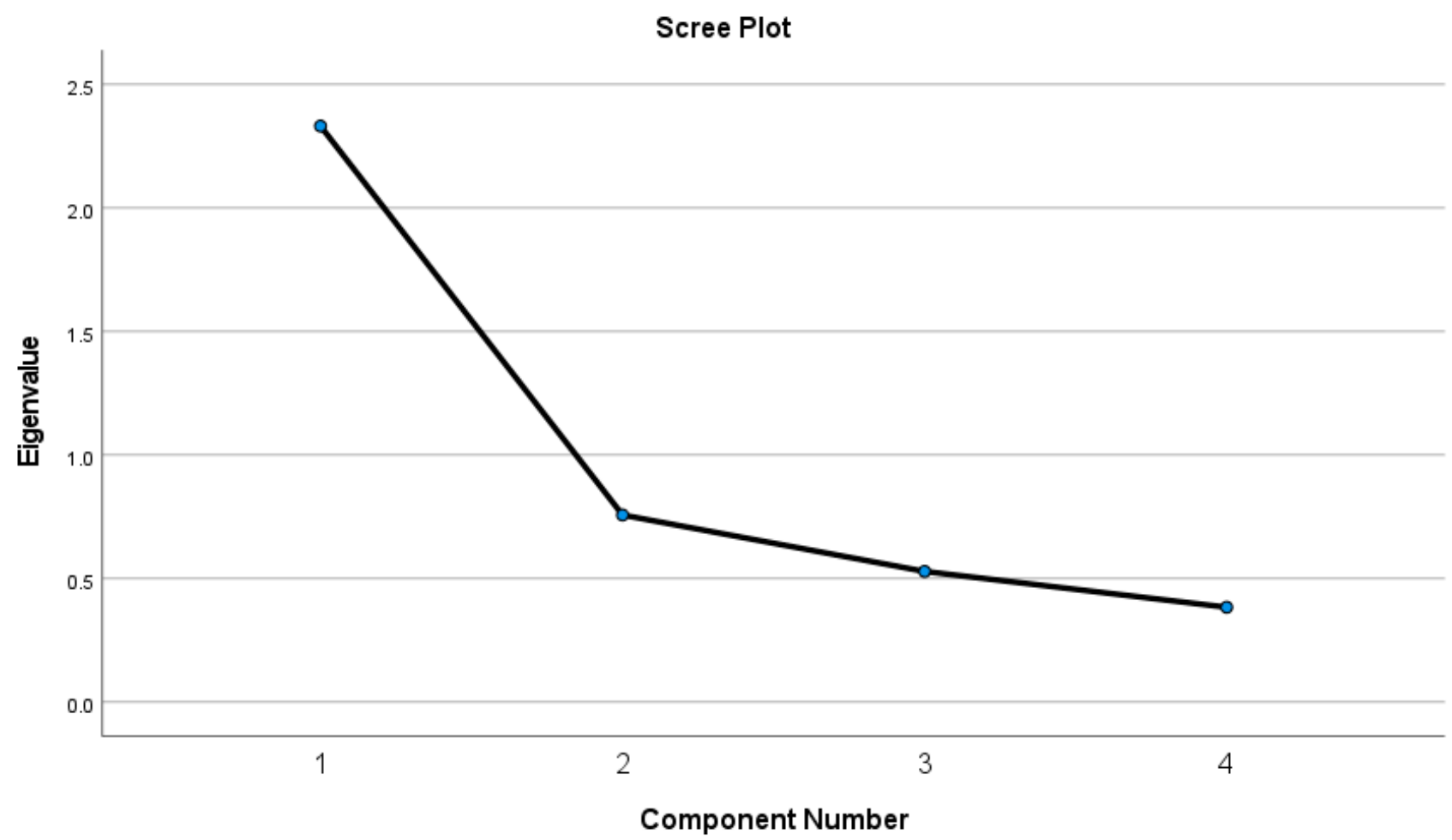

Figure 6. Scree plot in the principal component analysis regarding units responsible for the implementation process.

Based on the Kaiser criterion, only one component was extracted. According to the value of the independent samples t-test there was no statistically significant difference between larger and smaller companies regarding the total responsibility score $t(58)=1.37$, $p>0.05$.

According to the conducted research, a significant number of respondents (41) do not have information about planned investments in technologies in the field of Industry 4.0. This means that enterprises do not plan such investments in the next 5 years, or the respondents are not a unit or part of the working group responsible for the development/implementation of the enterprise development strategy. Ten companies out of sixty surveyed, planning to implement Industry 4.0 solutions in the next 5 years, indicate little awareness of the importance of the topic.

According to the respondents' answers (Table 14 below), only $16.67 \%$ of enterprises include the implementation of Industry 4.0 solutions in their strategy for the next 5 years. Therefore, an additional important determinant was included to indicate the elements 
supporting the decision of Industry 4.0 implementation as well as the degree to which these elements support the decision process (Table 15 below). The answers were assessed by the respondents using a five-point Likert scale in which different ratings had the following meaning: 1 = means the minimum level of support; $2=$ means a low level of support; $3=$ means neutral support level; $4=$ indicates a high level of support; $5=$ means a significant level of support. The survey results indicate that there is no agreement among the respondents as to the degree of support for individual elements impacting the decision to implement Industry 4.0 solutions. For the five items comprising the question, scores above the average prevail; in the case of the item, 'Determining individual implementation results for the enterprise', scores below the average of the scale used prevail.

Table 14. The company's development strategy including the implementation of Industry 4.0 solutions in the next 5 years.

\begin{tabular}{cc}
\hline $\begin{array}{c}\text { The Company's Development Strategy Including the } \\
\text { Implementation of Industry } \mathbf{4 . 0}\end{array}$ & No. of Respondents \\
\hline Yes, to a large extent & 1 \\
\hline Yes & 1 \\
\hline Yes, but only as pilot or R\&D projects & 8 \\
\hline I do not know & 41 \\
\hline No & 9 \\
\hline R\&D-Research and development.
\end{tabular}

Table 15. Decision-making process to implement Industry 4.0.

\begin{tabular}{|c|c|c|c|c|c|}
\hline $\begin{array}{l}\text { Likert Scale: } \\
\text { Elements and the Degree of Support for the Decision-Making } \\
\text { Process to Implement Industry } 4.0 \text { Solutions }\end{array}$ & 1 & 2 & 3 & 4 & 5 \\
\hline Expanding knowledge about available technologies & 9 & 7 & 15 & 12 & 17 \\
\hline Expanding knowledge about available solutions & 10 & 8 & 20 & 10 & 12 \\
\hline Implementation of a pilot project & 24 & 0 & 10 & 19 & 7 \\
\hline Case study in the same industry & 16 & 5 & 14 & 19 & 6 \\
\hline Establishing individual implementation results for the company & 23 & 3 & 17 & 9 & 8 \\
\hline Support of a consulting company/expert in the implementation & 11 & 14 & 9 & 20 & 6 \\
\hline
\end{tabular}

Table 16 presents mean values acquired on the Likert scales regarding the degree of support for the decision-making process to implement Industry 4.0 solutions in companies employing up to 249 participants and in companies employing at least 250 participants with the values of the Mann-Whitney U test.

The assessment for the case study in the same industry was significantly higher in companies employing at least 250 employees. The assessment for establishing individual implementation results for the company and support of a consulting company/expert in the implementation was significantly higher in companies employing up to 249 employees.

The results from the Likert scales were also analysed with the use of principal component analysis with oblique Oblimin rotation. The acquired scree plot is depicted in Figure 7. 
Table 16. Assessment of the degree of support for the decision-making process to implement Industry 4.0 solutions in companies employing up to 249 participants and in companies employing at least 250 participants.

\begin{tabular}{|c|c|c|c|c|}
\hline $\begin{array}{l}\text { Number of Employees: } \\
\text { Elements and the Degree of Support for the Decision-Making } \\
\text { Process to Implement Industry 4.0 Solutions }\end{array}$ & 1-249 & $250+$ & $\mathbf{U}$ & $p$ \\
\hline Expanding knowledge about available technologies & 3.30 & 3.39 & 425.00 & 0.755 \\
\hline Expanding knowledge about available solutions & 2.89 & 3.27 & 381.50 & 0.328 \\
\hline Implementation of a pilot project & 3.15 & 2.42 & 345.50 & 0.117 \\
\hline Case study in the same industry & 2.48 & 3.24 & 317.50 & 0.049 \\
\hline Establishing individual implementation results for the company & 3.00 & 2.27 & 316.50 & 0.045 \\
\hline Support of a consulting company/expert in the implementation & 3.41 & 2.55 & 283.00 & 0.013 \\
\hline
\end{tabular}

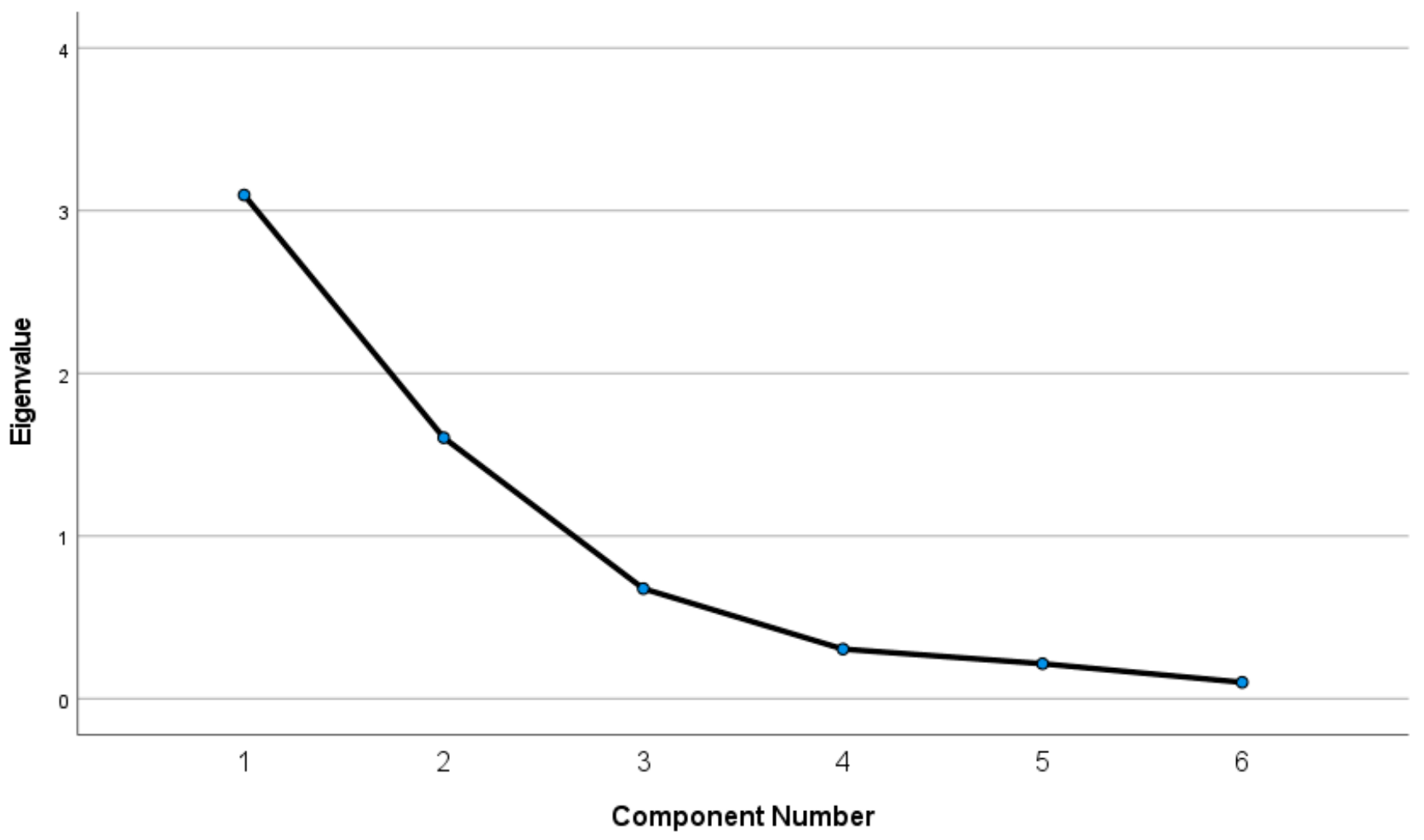

Figure 7. Scree plot in the principal component analysis regarding support for the decision-making process to implement Industry 4.0 solutions.

Based on the Kaiser criterion, two components were extracted. Table 17 presents factor loadings in a pattern matrix. The values lower than 0.4 were suppressed for clarity. This exclusion ensures that the factor loadings will be higher than the minimal level for interpretation of structure, which is considered to be in the range 0.30 to \pm 0.40 (Hair et al. 2019). 
Table 17. Pattern matrix acquired in the principal component analysis regarding support for the decision-making process to implement Industry 4.0 solutions.

\begin{tabular}{ccc}
\hline Item & $\begin{array}{c}\text { Factor 1 } \\
\text { Results Factor }\end{array}$ & $\begin{array}{c}\text { Factor 2 } \\
\text { Knowledge Factor }\end{array}$ \\
\hline $\begin{array}{c}\text { Establishing individual implementation results } \\
\text { for the company }\end{array}$ & 0.95 & \\
\hline $\begin{array}{c}\text { Implementation of a pilot project } \\
\text { implementation }\end{array}$ & 0.92 & 0.87 \\
\hline $\begin{array}{c}\text { Support of a consulting company / expert in the } \\
\text { Expanding knowledge about available solutions }\end{array}$ & 0.82 & 0.83 \\
\hline Case study in the same industry & 0.68 \\
\hline Expanding knowledge about available \\
technologies
\end{tabular}

Based on the factor loadings, two factors were extracted. Taking the items' contents into consideration, the first factor was named 'Results Factor', and the second factor was named 'Knowledge Factor'.

According to the values of the independent samples t-test, there was a statistically significant difference between companies employing 1-249 workers and companies employing at least 250 workers regarding 'Results Factor', $t(57.95)=2.42, p<0.05$. The difference regarding the 'Knowledge Factor' was a statistically insignificant, $t$ (47.11) = $-1.39, p>0.05$. The mean value of the results factor was higher in smaller companies (see Figure 8).

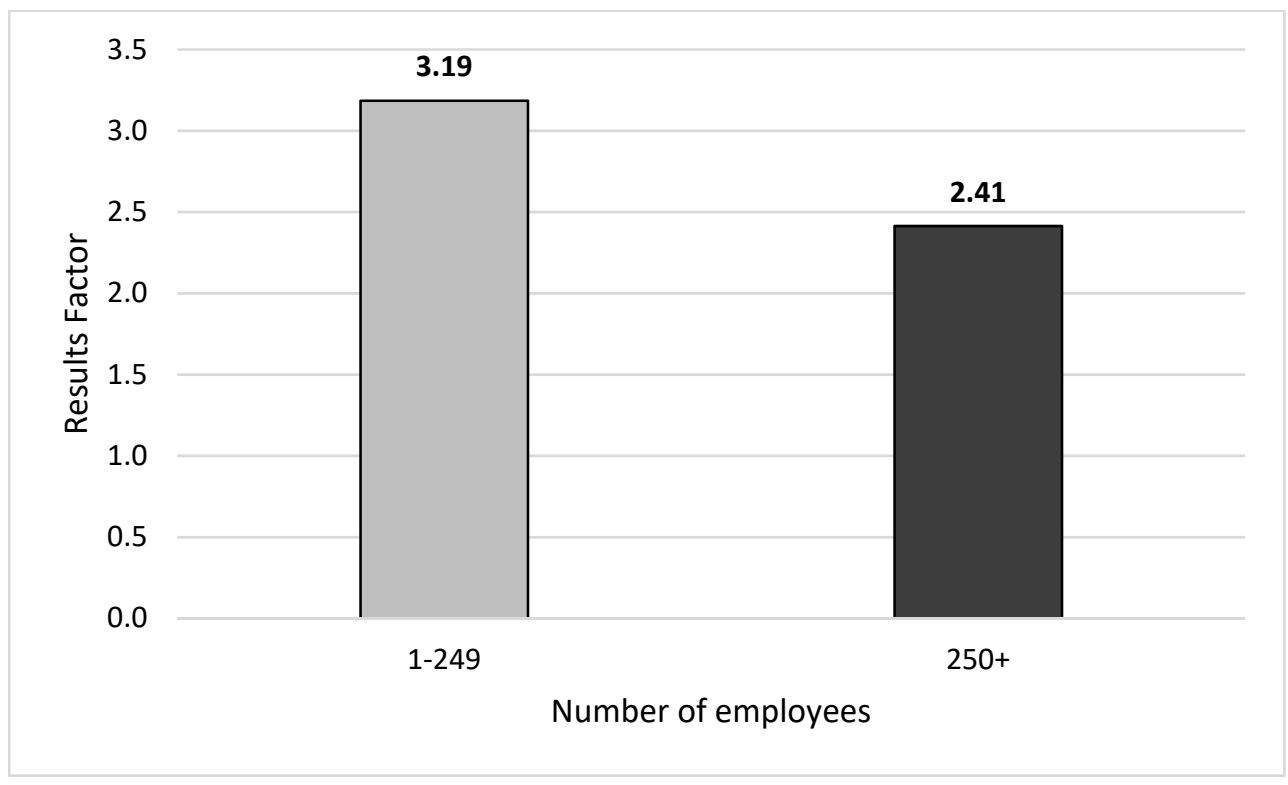

Figure 8. Mean values of results factor in companies employing 1-249 workers and in companies employing at least 250 workers.

\section{Discussion of Results}

The latest report by Deloitte's State of AI in the Enterprise, 3rd Edition (Ammanath et al. 2020), which examines the approach of various companies to the implementation of artificial intelligence solutions, indicates that by 2023 the level of global spending on AI implementation will increase by more than 2.5 times compared to 2019. Despite such a dynamic development of new technologies in the area of Industry 4.0 - not only those 
related to AI-in the Polish industrial sector, similar solutions are still perceived more as a futuristic curiosity than as a natural stage of industry evolution.

Our hypothesis examined the influence of the size of Polish industrial enterprises on the level of knowledge of Industry 4.0 solutions.

Statistical differences between companies employing up to 249 participants and companies employing at least 250 participants were verified with the use of the Mann-Whitney $\mathrm{U}$ test. The Likert scales were also analysed with the use of the principal component analysis. The extracted factors were also compared between companies employing up to 249 participants and companies employing at least 250 participants.

The research results at hand allow for drawing the following conclusions for the hypothesis. The research results show statistically significant differences regarding Industry 4.0 implementation benefits. The mean value of product-based benefits was higher in smaller companies, while optimisation-based benefits were higher in larger companies. This indicates that large and recognisable companies are looking for cost optimisation in Industry 4.0 solutions, whereas small companies are looking for an opportunity to increase brand recognition.

The assessment of management board responsibility was significantly lower in companies employing at least 250 employees. This is probably due to an extensive organisation that often includes specialists in the field of innovation.

Regarding support for the decision-making process to implement Industry 4.0 solutions, the mean value of results factor was higher in smaller companies. This probably results from the smaller technical and financial capabilities of small businesses.

The research results shown no statistically significant differences between larger and smaller companies regarding the knowledge factor, competencies, barriers and responsibilities. This indicates a similar level of expectations in terms of competences and responsibilities as well as similar barriers regardless of the size of the company.

Regardless of the differences and similarities between large and small companies, the results of the research showed an insufficient level of knowledge in the field of Industry 4.0 solutions, as well as a lack of awareness about the possibilities of supporting the development of the enterprise by specialised technology providers. Only a small portion of the surveyed companies decided to implement advanced technological solutions, and moreover, most of the respondents had no contact with providers of technologies related to Industry 4.0. The awareness of enterprises as to the offers of suppliers of advanced technological solutions is also low. Most of the respondents have never had contact with companies offering such solutions. Increasing the awareness of the respondents themselves and increasing their involvement in the implementation of Industry 4.0 may also be assisted by increasing employees' passion for work (Ahadiat and Dacko-Pikiewicz 2020). Low awareness also explains the lack of digital culture, training and awareness about the new challenges facing Industry 4.0 (Hariharasudan and Kot 2018). Therefore, it is not surprising that most respondents do not know whether companies plan to implement Industry 4.0 in their development strategies for the next 5 years. The implementation of Industry 4.0 solutions is perceived by the respondents as so innovative and strategic that they indicate the top management of the company as responsible for decisions on possible implementations. It can therefore be concluded that the solutions offered under Industry 4.0 are perceived by enterprises to a great extent as a revolution rather than an evolution. It is worth emphasising here that from the catalogue of barriers related to the implementation of new technologies, the respondents assign ultimate blame to financial barriers and, first and foremost, the lack of qualified staff. Since companies are sociotechnical systems, one must consider the role of people in a smart factory, because Industry 4.0 brings important opportunities as well as difficult challenges for people (Fortuny-Santos et al. 2020). This means that the lack of appropriate training paths and programs may be the main factor slowing down the implementation of Industry 4.0 technology in Polish industrial enterprises. The need to educate and build awareness of Polish entrepreneurs in the area of Industry 4.0 through various training programs was 
also indicated by other researchers of the Polish market (Sasiadek and Basl 2018; Gracel and Makowiec 2017).

\section{Conclusions}

This research aims to present the awareness, readiness and ability of enterprises to implement Industry 4.0 solutions. The conducted research proves that Polish industrial enterprises have little awareness of the essence and role of Industry 4.0 and a low level of knowledge about the available technological solutions regardless of their size and affiliation to larger international organisations.

The implications for practical implementation include the need for additional support in the area of technological, financial and human resources challenges. It is worth emphasising that from the catalogue of barriers, the respondents indicated above all the lack of qualified staff, which means that there is a need to introduce appropriate training paths and programs supporting the implementation of Industry 4.0 technology in Polish industrial enterprises. The implications for practical implementation include, in particular, the need for additional support for SME investments in Industry 4.0 technologies in the area of technological, financial and human resources challenges.

The authors of the article are aware of the limited scope of research that was carried out on a relatively small research sample. Regarding future lines of research, the need to expand the research sample so that it is representative on a national scale should be considered. This type of research would allow for accurately identifying the needs of Polish industry with respect to the need to increase knowledge about Industry 4.0 as well as to enable the effective development of training programs.

Author Contributions: Conceptualization: B.J., E.S. and S.S.; Data curation: B.J. and S.S.; Formal analysis: B.J., E.S. and S.S.; Funding acquisition: B.J. and M.L.; Investigation: B.J. and E.S.; Methodology, B.J., E.S. and S.S.; Project administration: B.J.; Resources: M.L.; Validation: M.L.; Writing-original draft: B.J.; Writing-review and editing, E.S. and M.L. All authors have read and agreed to the published version of the manuscript.

Funding: The project is funded under the program of the Minister of Science and Higher Education entitled "Regional Initiative of Excellence" in 2019-2022, project number 018/RID/2018/19, the amount of funding PLN 10788 423,16.

Institutional Review Board Statement: Not applicable.

Informed Consent Statement: Not applicable.

Data Availability Statement: Not applicable.

Conflicts of Interest: The authors declare no conflict of interest.

\section{References}

Abdallah, Aisha, Mohd Aizaini Maarof, and Anazida Zainal. 2016. Fraud detection system: A survey. Journal of Network and Computer Applications 68: 90-113. [CrossRef]

Ahadiat, Ayi, and Zdzisława Dacko-Pikiewicz. 2020. Effects of ethical leadership and employee commitment on employees' work passion. Polish Journal of Management Studies 21: 24-35. [CrossRef]

Ammanath, Beena, David Jarvis, and Susanne Hupfer. 2020. Thriving in the era of pervasive AI. In Deloitte's State of AI in the Enterprise, 3rd ed. Available online: https:/ / www2.deloitte.com/us/en/insights/focus/cognitive-technologies/state-of-ai-and-intelligentautomation-in-business-survey.html?id=us:2el:3pr:4di6462:5awa:6di:MMDDYY:\&pkid=1006825 (accessed on 7 March 2021).

Anand, Gopesh, and Peter T. Ward. 2004. Fit, flexibility and performance in manufacturing: Coping with dynamic environment. Production and Operations Management 13: 369-85. [CrossRef]

Ashton, Kevin. 2009. That 'Internet of Things' Thing. RFID Journal 22: 97-114. Available online: www.rfidjournal.com/article/view/ 4986 (accessed on 7 March 2021).

Atzori, Luigi, Antonio Iera, and Giacomo Morabito. 2010. The internet of things: A survey. Computer Networks 54: 2787-805. [CrossRef]

Azuma, Ronald, Reinhold Behringer, Steven Feiner, Simon Julier, and Blair Macintyre. 2001. Recent Advances in Augmented Reality. IEEE Computer Graphics and Applications 21: 34-47. [CrossRef] 
Bechtold, Jochen, Andreas Kern, Christoph Lauenstein, and Lena Bernhofer. 2014. Industry 4.0-The Capgemini Consulting View. Available online: https://www.de.capgemini-consulting.com/resource-fileaccess/resource/pdf/capgemini-consultingIndustry-4.0_0.pdf (accessed on 8 March 2021).

Brecher, Christian, Stefan Kozielski, and Lutz Schapp. 2011. Integrative Production Technology for High-Wage Countries. Berlin/Heidelberg: Springer.

Camisón-Haba, Sergio, Jose A. Clemente-Almendros, and Tomas Gonzalez-Cruz. 2019. How technology-based firms become also highly innovative firms? The role of knowledge, technological and managerial capabilities, and entrepreneurs' background. Journal of Innovation \& Knowledge 4: 162-70.

Cardoso, Jorge, Konrad Voigt, and Matthias Winkler. 2008. Service Engineering for the Internet of Services. Enterprise Information Systems 19: 15-27. [CrossRef]

Cooper, Joshua, and Anne James. 2009. Challenges for database management in the Internet of things. IETE Technical Review 26: 320-29. [CrossRef]

Cservenák, Ákos, Makó Ildikó, and Csáki Tibor. 2014. Creating a virtual robotic cell with robotexpert software system. Paper presented at 28th International Multidisciplinary Scientific Conference, Miskolc, Hungary, April 10-11.

Davenport, Thomas H., Paul Barth, and Randy Bean. 2012. How big data is different. MIT Sloan Management Review 54: 43-46.

Dudás, Laszlo. 2010. Advanced software tool for modelling and simulation of new gearings. International Journal of Design Engineering 3: 289-310. [CrossRef]

Edvardsson, Ingi Runar, and Susanne Durst. 2013. The Benefits of Knowledge Management in Small and Medium-Sized Enterprises. The Procedia-Social and Behavioral Sciences 81: 351-54. [CrossRef]

Fortuny-Santos, Jordi, Patxi Ruiz-de-Arbulo López, Itziar Lujan-Blanco, and Ping-Kuo Chen. 2020. Assessing the Synergies between Lean Manufacturing and Industry 4.0. Available online: https://upcommons.upc.edu/bitstream/handle/2117/328041/ DyOsmartleanR1.pdf (accessed on 6 May 2021).

Ganzarain, Jaione, and Nekane Errasti. 2016. Three stage maturity model in SME's toward industry 4.0. Journal of Industrial Engineering and Management 9: 1119-28. [CrossRef]

Gashenko, Irina V., Natalia N. Khakhonova, Irina V. Orobinskaya, and Yulia S. Zima. 2020. Competition between human and artificial intellectual capital in production and distribution in Industry 4.0. Journal of Intellectual Capital 21: 531-47. [CrossRef]

Genovese, Andrea, Lenny Koh, Niraj Kumar, and Pradhumn Kumar Tripathi. 2014. Exploring the challenges in implementing supplier environmental performance measurement models: A case study. Production Planning \& Control 25: 1198-211.

Gracel, Jarosław, and Marek Makowiec. 2017. Kluczowe kompetencje menedżera w dobie czwartej rewolucji przemysłowej—Przemysłu 4.0. Zarządzanie XLIV-nr 4. Acta Universitatis Nicolai Copernici 44: 105-29. Available online: https://apcz.umk.pl/czasopisma/ index.php/AUNC_ZARZ/article/viewFile/AUNC_ZARZ.2017.054/13803 (accessed on 7 March 2021). [CrossRef]

Gubán, Miklós, Gyorgy Kovács, and Sebastian Kot. 2017. Simulation of complex logistical service processes. Management and Production Engineering Review 8: 19-29. [CrossRef]

Hair, Joseph F., William C. Black, Barry J. Babin, and Rolph E. Anderson. 2019. Multivariate Data Analysis. Boston: Cengage Learning USA.

Haller, Stephan, Stamatis Karnouskos, and Christoph Schroth. 2008. The Internet of Things in an Enterprise Context. In Future Internet-FIS 2008. Edited by John Domingue, Dieter Fensel and Paolo Traverso. FIS 2008. Lecture Notes in Computer Science. Berlin/Heidelberg: Springer, vol. 5468. [CrossRef]

Hariharasudan, A., and Sebastian Kot. 2018. A scoping review on Digital English and Education 4.0 for Industry 4.0. Social Sciences 7: 227. [CrossRef]

Hellinge, Ariane, and Heinrich Seeger. 2011. Cyber-Physical Systems Driving Force for Innovation in Mobility, Health, Energy and Production. Munich: acatech-National Academy of Science and Engineering.

Hermann, Mario, Tobias Pentek, and Boris Otto. 2016. Design Principles for Industrie 4.0 Scenarios. Paper presented at Annual Hawaii International Conference on System Sciences, Koloa, HI, USA, January 5-8; pp. 3928-37.

Inshakova, Agnessa O., Evgenia E. Frolova, Ekaterina P. Rusakova, and Sergey I. Kovalev. 2020. The model of distribution of human and machine labor at intellectual production in industry 4.0. Journal of Intellectual Capital 21: 601-22. [CrossRef]

Kagermann, Henning. 2015. Change Through Digitization-Value Creation in the Age of Industry 4.0. In Management of Permanent Change. Berlin/Heidelberg: Springer.

Kagermann, Henning, Wolfgang Wahlster, and Johannes Helbig. 2013. Recommendations for Implementing the Strategic Initiative INDUSTRIE 4.0. Procedia CIRP 19: 51-56. [CrossRef]

Kopetz, Hermann. 2011. Real-Time Systems. In Real-Time Systems: Design Principles for Distributed Embedded Applications. Boston: Springer, pp. 307-23.

Kovács, György. 2020. Combination of Lean value-oriented conception and facility layout design for even more significant efficiency improvement and cost reduction. International Journal of Production Research 58: 2916-36. [CrossRef]

Lee, Jay, Behrad Bagheri, and Hung-An Kao. 2015. A Cyber-Physical Systems architecture for Industry 4.0-based manufacturing systems. Manufacturing Letters 3: 18-23. [CrossRef]

Leitao, Paulo, Armando Walter Colombo, and Stamatis Karnouskos. 2016. Industrial automation based on cyber-physical systems technologies: Prototype implementations and challenges. Computers in Industry 81: 11-25. [CrossRef]

Li, Da Xu. 2011. Enterprise systems: State-of-the-art and future trends. IEEE Transactions on Industrial Informatics 7: 630-40. 
Lopes, João, Márcio Oliveira, Paulo Silveira, Luís Farinha, and José Oliveira. 2021. Business Dynamism and Innovation Capacity, an Entrepreneurship Worldwide Perspective. Journal of Open Innovation: Technology, Market and Complexity 7: 94. [CrossRef]

Machado, Carla Goncalves, Mats Winroth, Dan Carlsson, Peter Almström, Victor Centerholt, and Malin Hallin. 2019. Industry 4.0 readiness in manufacturing companies: Challenges and enablers towards increased digitalization. Procedia CIRP 81: 1113-18. [CrossRef]

Miorandi, Daniele, Sabrina Sicari, Francesco De Pellegrini, and Imrich Chlamtac. 2012. Internet of things: Vision, applications and research challenges. Ad Hoc Networks 10: 1497-516. [CrossRef]

Mokhtar, Siti Salwa Sheikh, Mahomed Anuar Shah Bali, Aziz Yuhanis Abdul, and Rahman Suhaimi Ab. 2020. Industry 4.0: The importance of innovation in adopting cloud computing among smes in Malaysia. Polish Journal of Management Studies 22: 310-22. [CrossRef]

Monostori, Laszlo, Botond Kádár, Thomas Bauernhansl, Shinsutce Kondoh, Soundar Kumara, Gunther Reinhart, Olaf Sauer, Günther Schuh, Wilfried Sihn, and Kanji Ueda. 2016. Cyber-physical systems in manufacturing. CIRP Annals 65: 621-41. [CrossRef]

Mourtzis, Dimitris, Ekaterini Vlachou, and Nikolaos Milas. 2016. Industrial Big Data as a Result of IoT Adoption in Manufacturing. Procedia CIRP 55: 290-95. [CrossRef]

Müller, Julian Marius, and Simon Däschle. 2018. Business Model Innovation of Industry 4.0 Solution Providers towards Customer Process Innovation. Processes 6: 260. [CrossRef]

Naqvi, Syed Turab Haider, Sami Farooq, and John Johansen. 2015. Operational performance: The impact of automation and integrated development. Paper presented at 22nd EurOMA Conference-Operations Management for Sustainable Competitiveness, Neuchâtel, Switzerland, June 26-July 1.

Nowotarski, Piotr, and Jerzy Paslawski. 2017. Industry 4.0 Concept Introduction into Construction SMEs. In IOP Conference Series: Materials Science and Engineering. Bristol: IOP Publishing, vol. 245, p. 052043. [CrossRef]

Oesterreich, Thuy Duong, and Frank Teuteberg. 2016. Understanding the implications of digitisation and automation in the context of Industry 4.0: A triangulation approach and elements of a research agenda for the construction industry. Computers in Industry 83: 121-39. [CrossRef]

Pereira, Ana Carolina Alves Caporali, and Fernando Romero. 2017. A review of the meanings and the implications of the Industry 4.0 concept. Paper presented at Manufacturing Engineering Society International Conference 2017, MESIC 2017, Vigo, Spain, June 28-30.

Posada, Jorge, Carlos Toro, Iñigo Barandiaran, David Oyarzun, Didier Stricker, Raffaele de Amicis, Eduardo Pinto, Peter Eisert, Jürgen Döllner, and Ivan Vallarino. 2015. Visual computing as a key enabling technology for industrie 4.0 and industrial internet. IEEE Computer Graphics and Applications 35: 26-40. [CrossRef] [PubMed]

Rashid, Asif, and Benny Tjahjono. 2016. Achieving manufacturing excellence through the integration of enterprise systems and simulation. Production Planning \& Control 27: 837-52.

Reischauer, Georg, and Karl-Heinz Leitner. 2016. Innovation 4.0: How to Analyze the Innovation Potential of Industry 4.0. Austrian Management Review 6: 76-83.

Romero, David, Peter Bernus, Ovidiu Noran, Johan Stahre, and Åsa Fast-Berglund. 2016. The Operator 4.0: Human Cyber-Physical Systems \& Adaptive Automation towards Human-Automation Symbiosis Work Systems. In APMS (Advances in Production Management Systems). Cham: Springer.

Sąsiadek, Michał, and Josef Basl. 2018. Świadomość i poziom wdrożenia koncepcji Przemysł 4.0 w wybranych polskich i czeskich przedsiębiorstwach. Available online: http:/ / www.ptzp.org.pl/files/konferencje/kzz/artyk_pdf_2018/T2/2018_t2_189.pdf (accessed on 7 March 2021).

Schmidt, Rainer, Michael Möhring, Ralf-Christian Härting, Christopher Reichstein, Pascal Neumaier, and Philip Jozinović. 2015. Industry 4.0-Potentials for Creating Smart Products: Empirical Research Results. Paper presented at International Conference on Business Information Systems, Poznań, Poland, June 24-26; pp. 16-27.

Schulze, Anne. 2014. Industrie 4.0 steht noch ganz am Anfang. Available online: http://www.flyacts.com/blog/industrie-4-0-stehtnoch-ganz-am-anfang/ (accessed on 7 March 2021).

Shariatzadeha, Navid, Thomas Lundholma, Lars Lindberga, and Gunilla Sivard. 2016. Integration of Digital Factory with Smart Factory Based on Internet of Things. Procedia CIRP 50: 512-17. [CrossRef]

Sommer, Lutz. 2015. Industrial revolution-Industry 4.0: Are German manufacturing SMEs the first victims of this revolution? Journal of Industrial Engineering and Management 8: 1512-32. Available online: http://jiem.org/index.php/jiem/article/view/1470 (accessed on 11 April 2021). [CrossRef]

Stock, Tim, and Guenther Seliger. 2016. Opportunities of Sustainable Manufacturing in Industry 4.0. Procedia CIRP 40: 536-41. [CrossRef]

Straka, Martin, Erik Žatkovic, and Róbert Schréter. 2014. Simulation as a means of activity streamlining of continuously and discrete production in specific enterprise. Acta Logistica 1: 11-16. [CrossRef]

Szczepańska-Woszczyna, Katarzyna, and Joanna Kurowska-Pysz. 2016. Sustainable business development through leadership in SMEs. Engineering Management in Production and Services 8: 57-69. [CrossRef]

Ślusarczyk, Beata. 2018. Industry 4.0: Are we ready? Polish Journal of Management Studies, 17. [CrossRef]

Ślusarczyk, Beata, and Paula Pypłacz. 2020. Industry 4.0 in Polish Smes in the Aspect of Innovation Possibilities. International Journal of Economics and Finance Studies 12: 102-14. 
Tesch da Silva, Schäfer Fernanda, Cristiano André da Costa, Cesar David Paredes Crovato, and Rodrigoda Rosa Righi. 2020. Looking at energy through the lens of Industry 4.0: A systematic literature review of concerns and challenges. Computers $\mathcal{E}$ Industrial Engineering 143: 106426. [CrossRef]

Vaníčková, Radka, and Katarzyna Szczepańska-Woszczyna. 2020. Innovation of business and marketing plan of growth strategy and competitive advantage in exhibition industry. Polish Journal of Management Studies 21: 425-45. [CrossRef]

Veeramani, Dharmaraj, John Bernardo, Chen Chung, and Yash Gupta. 1995. Computer Integrated Manufacturing: A Taxonomy of Integration and Research Issues. Production and Operations Management 4: 360-80. [CrossRef]

Vlčková, Miroslava, Petr Zeman, and Jiři Alina. 2019. Analysis of the Financial Indicators in the Enterprises Affected by Industry 4.0. Paper presented at 14th International Conference Liberec Economic Forum, Liberec, Czech Republic, September 17-18; pp. 346-52.

Vrchota, Jaroslav, and Martin Pech. 2019. Readiness of Enterprises in Czech Republic to Implement Industry 4.0: Index of Industry 4.0. Applied Sciences 9: 5405. [CrossRef]

Wamba, Samuel Fosso, Shahriar Akter, Andrew Edwards, Geoffrey Chopin, and Denis Gnanzou. 2015. How ‘Big Data' Can Make Big Impact: Findings from a Systematic Review and a Longitudinal Case Study. International Journal of Production Economics 165: 234-46. [CrossRef]

Wang, Shiyong, Jiafu Wan, Daqiang Zhang, Di Li, and Chunhua Zhang. 2016. Towards smart factory for industry 4.0: A self-organized multi-agent system with big data based feedback and coordination. Computer Networks 101: 158-68. [CrossRef]

Weyer, Stephan, Mathias Schmitt, Moritz Ohmer, and Dominic Gorecky. 2015. Towards Industry 4.0—Standardization as the Crucial Challenge for Highly Modular, Multi-Vendor Production Systems. IFAC-PapersOnLine 48: 579-84. [CrossRef]

Zhong, Ray, Chen Xu, Chao Chen, and George Huang. 2015. Big Data Analytics for Physical Internet-based intelligent manufacturing shop floors. International Journal of Production Research 55: 2610-21. [CrossRef]

Zhou, Keliang, Taigang Liu, and Lifeng Zhou. 2016. Industry 4.0: Towards Future Industrial Opportunities and Challenges. Paper presented at International Conference on Fuzzy Systems and Knowledge Discovery, Changsha, China, August 13-15; pp. 2147-52. 